\title{
Synthesis and evaluation of some surface active agents from long chain fatty amine
}

\author{
By A.M. F. Eissa
}

\author{
Chemistry Department, Faculty of Science, Benha University, Egypt. \\ ref_at@hotmail.com
}

\section{RESUMEN}

Síntesis y evaluación de algunos agentes surfactantes de aminas grasas de cadena larga.

Este estudio continua nuestra serie sobre la síntesis de agentes surfactantes que contienen grupos heterociclicos. $\mathrm{N}$-Heptadecanoyl-3-(4-oxo-4H-benzo[d][1,3]oxazin-2-yl)acrylamida (4) se usa como nueva materia prima para sintetizar surfactantes noiónico propenoxilado conteniendo herociclos tales como thiazol, triazol, benzoxazina, quinazolina, triazina, y oxazina. Las estructuras de los compuestos preparados se dilucidan mediante herramientas espectroscópicas (IR, ${ }^{1} \mathrm{H}$ NMR and espectroscopía de masas). Se determinan sus propiedades físicas, tensión superficial e interfacial, punto de nube, altura de espuma, poder de emulsificación y concentración micelar critica. También se revisan sus propiedades antimicrobianas y de biodegradabilidad $\mathrm{Se}$ encontró que los nuevos compuestos poseían destacadas propiedades superficiales y unas buenas actividades antimicrobianas.

PALABRAS-CLAVE: Actividad antimicrobiana - Actividad superficial - Síntesis

\section{SUMMARY}

Synthesis and evaluation of some surface active agents from long chain fatty amine.

This study continues our series of synthesis of surface active agents containing heterocyclic moiety. $N$ Heptadecanoyl-3-(4-oxo-4H-benzo[d][1,3]oxazin-2-yl)acrylamide (4) was used as a new starting material to synthesize propenoxylated nonionic surface active agents having heterocycles such as (thiazole, triazole, benzoxazine, quinazoline, triazine, and oxazine). The structures of the prepared compounds were elucidated by using spectroscopic tools (IR, ${ }^{1} \mathrm{H}$ NMR and Mass spectroscopy). Physical properties such as surface and interfacial tension, cloud point, foaming height, wetting time, emulsification power and critical micelle concentration (CMC) were determined. Antimicrobial and biodegradability properties were also screened. It was found that the produced novel groups of nonionic surface active agents have pronounced surface properties and good antimicrobial activities.

KEY- WORDS: Antimicrobial activity - Surface activity Synthesis.

\section{INTRODUCTION}

The most important category of fatty nonionic surfactants are synthesized by the oxyalkylation (with ethylene oxide and propylene oxide) of organic compounds containing active hydrogen in the presence of a base (Sallary, et al., 1997), acid as well as untraditional catalysts (Pegiadou, et al., 2001).

These compounds fulfill the following requirements:

a-Presence of long chain hydrocarbon $\left(C_{12}-C_{18}\right)$ that acts as amphiphilic part.

b-Presence of active hydrogen atoms $\left(\mathrm{NH}, \mathrm{NH}_{2}\right.$, $\mathrm{SH}, \mathrm{OH}$ and $\mathrm{COOH}$ ) in the molecule which are able to propyloxylate (Amin, et al., 2004; Lagerman, et al., 1994) to produce the hydrophobic part in a correct hydrophilichydrophobic balance (Pegiadou, et al., 2000)

It has recently been reported that surfactants containing heterocyclic moiety have bactericidal and antifungal activities as well as industrial importance (Amin, et al., 2004; Yassin, et al., 1994). 2-Substituted benzoxazolinone as well as their corresponding quinazoline derivatives have been reported to exhibit biological activities such as antipyretic, antiinflammatory, anticancer and antimitotic agents (Wasfy, et al.,1995).

Herien, as a part of our program (Eissa et al., 2006; Amin, et al., 2004; Amin, et al., 2003; Eissa, 2006) on the synthesis and characterization of different types of surface active agents, this manuscript describes the synthesis of a novel group of nonionic surface active agents containing heterocyclic moieties from low cost fatty amine (heptadecylamine)

\section{MATERIALS AND METHODS}

Melting points are uncorrected. IR spectra in $\mathrm{KBr}$ were measured on a Pye-Uncam SP-1000 infrared spectrophotometer on a $\mathrm{KBr}$ disk or nujol. The ${ }^{1} \mathrm{H}$ NMR spectra were obtained on a Varian EM-390-60 $\mathrm{MHz}$ spectrometer in DMSO as the solvent. Tetramethylsilane TMS served as an internal reference and chemical shifts are expressed as $d$ (ppm). Mass spectra were recorded on a GC/MS Finning-MAT. Microanalyses were preformed by the Micro analytical Unit at Cairo University. All the compounds gave satisfactory elemental analyses. Thin layer chromatography (TLC) was carried out 
on silica gel (MN-Kieselgel G., $0.2 \mathrm{~mm}$ thickness) and the plates were scanned under $254 \mathrm{~nm}$ ultraviolet light. Antimicrobial and antifungal activity tests were carried out by the microbiology Lab., Faculty of Science, Benha University, Egypt.

\subsection{3-Octadecylcarbamoyl-acrylic acid (2)}

A solution of octadecylamine (1) (0.01 mole) and maleic anhydride ( 0.01 mole) in petroleum ether (20 $\mathrm{ml}$ ) was refluxed for $3 \mathrm{hr}$, the reaction mixture was cooled and the separated solid was filtered off and crystallized from benzene to yield 2 as white precipitate, yield $80 \%$, mp $86-8{ }^{\circ} \mathrm{C}$. IR: $v 3430(\mathrm{OH})$, 3200 (NH), 2922, 2851 (CH aliphatic), 1710, 1770 (CO) and $1604 \mathrm{~cm}^{-1}(\mathrm{C}=\mathrm{C}) ;{ }^{1} \mathrm{H}$ NMR $\left(\mathrm{CDCl}_{3}\right): \delta 0.86$ (t, 3H, $\left.\mathrm{CH}_{3}\right), 1.29-1.33\left(\mathrm{~m}, 32 \mathrm{H}, \mathrm{CH}_{2}\right.$ in alkyl chain), $1.60\left(\mathrm{t}, 2 \mathrm{H}, \mathrm{CH}_{2} \mathrm{NH}\right), 6.6,6.9(2 \mathrm{~d}, 2 \mathrm{H}$, olefinic proton), $8.2(\mathrm{~s}, 1 \mathrm{H}, \mathrm{NH})$ and $10.7(\mathrm{~s}, 1 \mathrm{H}, \mathrm{OH})$; ms: $\mathrm{m} / \mathrm{z} 368$ (3.4) $\left(\mathrm{M}^{+}+1\right)$. Anal.Calcd. for $\mathrm{C}_{22} \mathrm{H}_{41} \mathrm{NO}_{3}$ (367.58): C,71.89; H,11.24; N, 3.84. Found C,71.91; $\mathrm{H}, 11.20 ; \mathrm{N}, 3.81$

\subsection{3-Octadecylcarbamoyl-acryloyl chloride (3)}

3-Octadecylcarbamoylacryloyl chloride (3) was prepared according to procedures described in [18].

\subsection{N-Octadecyl-3-(4-oxo-4H- benzo[d][1,3]oxazin-2-yl)acrylamide (4)}

A solution of 3 ( 0.015 mole) and anthranilic acid $(0.01 \mathrm{~mole})$ in dry pyridine $(30 \mathrm{ml})$ was refluxed for 3 $\mathrm{hr}$, the reaction mixture was cooled and poured into water and $\mathrm{HCl}(10 \mathrm{ml})$.The separated solid was filtered off and crystallized from toluene as yellow needles, yield $70 \%, \mathrm{mp} 126-8{ }^{\circ} \mathrm{C}$. IR: $v 3005(\mathrm{CH}$ aromatic), 2920, 2850 (CH aliphatic), 1763 (CO) and $1644 \mathrm{~cm}^{-1}(\mathrm{C}=\mathrm{N}) ;{ }^{1} \mathrm{H}$ NMR $\left(\mathrm{CDCl}_{3}\right): \delta 0.84(\mathrm{t}$, $\left.3 \mathrm{H}, \mathrm{CH}_{3}\right), 1.29-1.33\left(\mathrm{~m}, 32 \mathrm{H}, \mathrm{CH}_{2}\right.$ in alkyl chain), $1.84\left(\mathrm{t}, 2 \mathrm{H}, \mathrm{CH}_{2} \mathrm{NH}\right), 6.3,6.6(2 \mathrm{~s}, 2 \mathrm{H}$, olefinic proton), 7.56-8.10 (m, $4 \mathrm{H}, \mathrm{ArH}$ and $\mathrm{NH}$ protons). Anal.Calcd. for $\mathrm{C}_{29} \mathrm{H}_{44} \mathrm{~N}_{2} \mathrm{O}_{3}$ (468.69): C,74.32; $\mathrm{H}, 9.46$; N, 5.98. Found C,74.34; H,9.46; N, 5.96.

\subsection{N-Octadecyl-3-(4-oxo-3,4- dihydroquinazolin-2-yl)acrylamide (5)}

A fusion of 4 (0.01 mole) and ammonium acetate (0.01 mole) above thier melting points for 2 $\mathrm{hr}$ was carried out and after cooling, the separated solid was crystallized from ethanol to yield $76 \%$, $\mathrm{mp} \mathrm{105-7}{ }^{\circ} \mathrm{C}$. IR: v 3341-3300 (2NH), $3030(\mathrm{CH}$ aromatic), 2920, 2850 (CH aliphatic), $1680 \mathrm{~cm}^{-1}$ (2CO); ${ }^{1} \mathrm{H}$ NMR (DMSO- $\left.\mathrm{d}_{6}\right): \delta 0.85\left(\mathrm{t}, 3 \mathrm{H}, \mathrm{CH}_{3}\right)$, 1.28-1.32 (m, 32H, $\mathrm{CH}_{2}$ in alkyl chain), 1.64 (t, $2 \mathrm{H}$, $\left.\mathrm{CH}_{2} \mathrm{NH}\right), 6.1,6.5$ (2d, $2 \mathrm{H}$, olefinic proton), 7.61-7.75 $(\mathrm{m}, 4 \mathrm{H}, \mathrm{ArH})$ and $8.6(2 \mathrm{bs}, 2 \mathrm{H}, 2 \mathrm{NH})$. Anal. Calcd.for $\mathrm{C}_{29} \mathrm{H}_{45} \mathrm{~N}_{3} \mathrm{O}_{2}$ (467.70): C,74.48; H, 9.70; N, 8.98. Found $\mathrm{C}, 74.48 ; \mathrm{H}, 9.68 ; \mathrm{N}, 8.95$.

\subsection{3-(3-Amino-4-oxo-3,4-dihydroquinazolin- 2-yl)-N-octadecylacrylamide (6)}

A solution of 4 (0.01 mole) and hydrazine hydrate $(0.015$ mole $)$ in dry benzene $(30 \mathrm{ml})$ was refluxed for $3 \mathrm{hr}$. Then, the solution was concentrated and poured into water $(20 \mathrm{ml})$. The yellow precipitate formed was filtered off, dried and crystallized from ethanol, yield $78 \%$, mp 92-94 ${ }^{\circ} \mathrm{C}$. IR: $v 3178\left(\mathrm{NH}_{2}\right), 3020$ (CH aromatic), 2918, 2849 (CH aliphatic), $1688(\mathrm{CO})$, and $1585 \mathrm{~cm}^{-1}(\mathrm{C}=\mathrm{N}) ;{ }^{1} \mathrm{H}$ NMR: $\left(\mathrm{CDCl}_{3}\right) \delta 0.84\left(\mathrm{t}, 3 \mathrm{H}, \mathrm{CH}_{3}\right), 1.20-1.24(\mathrm{~m}$, $32 \mathrm{H}, \mathrm{CH}_{2}$ in alkyl chain), 1.60 (t, $\left.2 \mathrm{H}, \underline{\mathrm{CH}}_{2} \mathrm{NH}\right), 5.62$ (s, $2 \mathrm{H}$, olefinic proton), 7.42-7.96 (m, $4 \mathrm{H}, \mathrm{ArH})$ and 8.65 (br.s, $3 \mathrm{H}, \mathrm{NH}$ and $\mathrm{NH}_{2}$ ). Anal.Calcd. for $\mathrm{C}_{29} \mathrm{H}_{46} \mathrm{~N}_{4} \mathrm{O}_{2}$ (482.72): C,72.16; H, 9.61; N, 11.61. Found C,71.16; H, 9.66; N, 11.65.

\subsection{N-Octadecyl-3-(3-oxo-2,3-dihydro- 1H-1,4,9,10a-tetraaza-phenanthren- 10-yl)acrylamide (7)}

A solution of 6 ( 0.01 mole) and chloroacetamide (0.01mole) in acetyl chloride $(40 \mathrm{ml})$ was refluxed for $3 \mathrm{hr}$ and then, poured into water $(20 \mathrm{ml})$. The separated solid was filtered off and crystallized from benzene to yield $60 \%, \mathrm{mp} 81-83{ }^{\circ} \mathrm{C}$. IR: v 3343 $(\mathrm{NH}), 3025$ ( $\mathrm{CH}$ aromatic), 2918, $2850(\mathrm{CH}$ aliphatic), 1685 (CO) and $1609 \mathrm{~cm}^{-1}(\mathrm{C}=\mathrm{C}) ;{ }^{1} \mathrm{H}$ NMR: $\left(\mathrm{CDCl}_{3}\right) \delta 0.80\left(\mathrm{t}, 3 \mathrm{H}, \mathrm{CH}_{3}\right), 1.29-1.33(\mathrm{~m}$, $32 \mathrm{H}, \mathrm{CH}_{2}$ in alkyl chain), 2.87 (t, $\left.2 \mathrm{H}, \mathrm{CH}_{2} \mathrm{NH}\right), 3.65$ (s, $2 \mathrm{H}, \mathrm{CH}_{2}$ of the ring), 6.1, $6.6(2 \mathrm{~d}, 2 \mathrm{H}$, olefinic proton), 7.40-7.75 (m, 4H, ArH) and 8.20 (br.s, $2 \mathrm{H}$, 2NH).ms: $\mathrm{m} / \mathrm{z} 519$ (34.16) $\mathrm{M}^{+}-2$. Anal. Calcd for $\mathrm{C}_{31} \mathrm{H}_{47} \mathrm{~N}_{5} \mathrm{O}_{2}$ (521.75): $\mathrm{C}, 71.36 ; \mathrm{H}, 9.08 ; \mathrm{N}$, 13.42.Found $\mathrm{C}, 71.32 ; \mathrm{H}, 9.11 ; \mathrm{N}, 13.42$.

\subsection{General procedure for preparation of Schiff bases $8 a, b$}

A mixture of 4 (0.01 mole) and the corresponding aldehydes $(0.01 \mathrm{~mole})$ in ethanol $(25 \mathrm{ml})$ was treated with concentrated $\mathrm{HCl}(0.5 \mathrm{ml})$ and refluxed for $2 \mathrm{~h}$. The reaction mixture after cooling was filtered and recrystallized from ethanol to give $8 a$ and $8 b$.

\section{3-[3-(Benzylidene-amino)-4-oxo- \\ 3,4-dihydroquinazolin-2-yl]- \\ $\mathrm{N}$-octadecylacrylamide (8a)}

Prepared from benzaldehyde with yield $80 \%$. mp 105-107 ${ }^{\circ} \mathrm{C}$. IR: $v 3220(\mathrm{NH}), 3010$ (CH aromatic), 2920-2850 ( $\mathrm{CH}$ in alkyl chain),1601 (C=C) and $1590 \mathrm{~cm}^{-1}(\mathrm{C}=\mathrm{N}) .{ }^{1} \mathrm{H}$ NMR: $\left(\mathrm{CDCl}_{3}\right) \delta 0.90(\mathrm{t}, 3 \mathrm{H}$, $\left.\mathrm{CH}_{3}\right), 1.29-1.33\left(\mathrm{~m}, 32 \mathrm{H}, \mathrm{CH}_{2}\right.$ in alkyl chain), 2.95 (t, $\left.2 \mathrm{H}, \mathrm{CH}_{2} \mathrm{NH}\right), 6.2,6.5(2 \mathrm{~d}, 2 \mathrm{H}$, olefinic proton), 7.22-7.76 (m, 9H, ArH), 8.1 (s, 1H, CH=N) and 8.20 (br.s, $1 \mathrm{H}, 1 \mathrm{NH}$ ). Anal. Calcd for $\mathrm{C}_{36} \mathrm{H}_{50} \mathrm{~N}_{4} \mathrm{O}_{2}$ (570.83): C,75.75; H,8.83; N, 9.82.Found C,75.79; $\mathrm{H}, 8.89 ; \mathrm{N}, 9.82$. 
3-\{3-[(4-Chlorobenzylidene)amino]-4-oxo3,4-dihydroquinazolin-2-yl\}$\mathrm{N}$-octadecylacrylamide (8b)

Prepared from p-chlorobenzaldehyde. Yield 80 \%. mp 110-112 ${ }^{\circ} \mathrm{C}$. IR: $v 3250(\mathrm{NH}), 3007$ (CH aromatic), $2920-2850$ (CH in alkyl chain), 1600 $(\mathrm{C}=\mathrm{C})$ and $1595 \mathrm{~cm}^{-1}(\mathrm{C}=\mathrm{N}) .{ }^{1} \mathrm{H}$ NMR: $\left(\mathrm{CDCl}_{3}\right)$

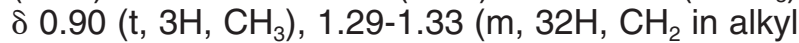
chain), 2.88 (t, $\left.2 \mathrm{H}, \underline{\mathrm{CH}}_{2} \mathrm{NH}\right), 6.1,6.6(2 \mathrm{~d}, 2 \mathrm{H}$, olefinic proton), 7.20-7.70 (m, 8H, ArH), $8.0(\mathrm{~s}, 1 \mathrm{H}$, $\mathrm{CH}=\mathrm{N}$ ) and 8.5 (br.s, $1 \mathrm{H}, 1 \mathrm{NH})$. Anal. Calcd for $\mathrm{C}_{36} \mathrm{H}_{49} \mathrm{CIN}_{4} \mathrm{O}_{2}$ (605.27): $\mathrm{C}, 71.44 ; \mathrm{H}, 8.16$; N,9.26.Found C,71.45; H,8.15; N,9.32.

\subsection{General procedure for preparation of $9 a, b$}

Thioglycillic acid $(0.01 \mathrm{~mol})$ was added to a solution of Schiff base $8 a, b(0.01 \mathrm{~mol})$ in dry acetone. The reaction mixture was refluxed for $3 \mathrm{~h}$. A solid product was obtained after cooling to give the adduct $9 a$ and $9 b$ which was crystallized from ethanol.

N-Octadecyl-3-[4-oxo-3-(4-oxo-2phenylthiazolidin-3-yl)-3,4-dihydroquinazolin2-yl]acrylamide (9a)

Yield 65 \%. mp 85-87 ${ }^{\circ} \mathrm{C}$. IR: v 3220 (NH), 3015 (CH aromatic), 2920-2850 (CH in alkyl chain), 1670 $(\mathrm{C}=\mathrm{O}), 1612(\mathrm{C}=\mathrm{C}), 1597(\mathrm{C}=\mathrm{N})$ and $692 \mathrm{~cm}^{-1}(\mathrm{C}-\mathrm{S})$. ${ }^{1} \mathrm{H}$ NMR: $\left(\mathrm{CDCl}_{3}\right) \delta 0.85\left(\mathrm{t}, 3 \mathrm{H}, \mathrm{CH}_{3}\right), 1.01-1.25(\mathrm{~m}$, $32 \mathrm{H}, \mathrm{CH}_{2}$ in alkyl chain), $1.87\left(\mathrm{t}, 2 \mathrm{H}, \mathrm{CH}_{2} \mathrm{NH}\right), 3.55$ (s, $2 \mathrm{H}, \mathrm{COCH}_{2} \mathrm{~S}$ ), 3.87 (septet, $1 \mathrm{H}$, methine proton), 6.2, 6.5 (2d, $2 \mathrm{H}$, olefinic proton), 7.25-7.70 $(\mathrm{m}, 8 \mathrm{H}, \mathrm{ArH})$ and 7.86 (br.s, $1 \mathrm{H}, 1 \mathrm{NH})$. Anal. Calcd for $\mathrm{C}_{38} \mathrm{H}_{52} \mathrm{~N}_{4} \mathrm{O}_{3} \mathrm{~S}$ (644.93): $\mathrm{C}, 70.77 ; \mathrm{H}, 8.13$; $\mathrm{N}, 8.69$.Found $\mathrm{C}, 70.74 ; \mathrm{H}, 8.12 ; \mathrm{N}, 8.74$.

\section{3-\{3-[2-(4-Chlorophenyl)-4-oxothiazolidin-3-yl]- 4-oxo-3,4-dihydroquinazolin-2-yl\}- $\mathrm{N}$-octadecylacryl-amide (9b)}

Yield 65 \%. mp 88-90 ${ }^{\circ} \mathrm{C}$. IR: $v 3200(\mathrm{NH}), 3005$ (CH aromatic), 2920-2850 ( $\mathrm{CH}$ in alkyl chain), 1677 $(\mathrm{C}=\mathrm{O}), 1612(\mathrm{C}=\mathrm{C}) 1590(\mathrm{C}=\mathrm{N})$ and $696 \mathrm{~cm}^{-1}(\mathrm{C}-\mathrm{S})$. ${ }^{1} \mathrm{H}$ NMR: $\left(\mathrm{CDCl}_{3}\right) \delta 0.95\left(\mathrm{t}, 3 \mathrm{H}, \mathrm{CH}_{3}\right), 1.29-1.33(\mathrm{~m}$, $32 \mathrm{H}, \mathrm{CH}_{2}$ in alkyl chain), 2.79 (t, $\left.2 \mathrm{H}, \mathrm{CH}_{2} \mathrm{NH}\right), 4.9$ (s, $2 \mathrm{H}, \mathrm{COCH}_{2} \mathrm{~S}$ ), 3.78 (septet, $1 \mathrm{H}$, methine proton), $5.9,6.3$ (2d, $2 \mathrm{H}$, olefinic proton), 7.20-7.70 (m, 9H, ArH) and 8.2 (br.s, 1H, 1NH). Anal. Calcd for $\mathrm{C}_{38} \mathrm{H}_{51} \mathrm{CIN}_{4} \mathrm{O}_{3} \mathrm{~S}$ (679.37): $\mathrm{C}, 67.18 ; \mathrm{H}, 7.57$; $\mathrm{N}, 8.25$.Found $\mathrm{C}, 67.20 ; \mathrm{H}, 7.61 ; \mathrm{N}, 8.22$.

\subsection{N-Octadecyl-3-(4-oxo-3-thioureido-3,4- dihydroquinazolin-2-yl)acrylamide (10)}

A solution of 4 (0.01mole) and thiosemicarbazide (0.01mole) in pyridine $(30 \mathrm{ml})$ was refluxed for $3 \mathrm{hr}$, the reaction mixture was cooled and poured into cold water and $\mathrm{HCl}$. The solid that separated was filtered off and crystallized from ethanol to yield $60 \%$, mp 98-100 ${ }^{\circ} \mathrm{C}$. IR: $v 3425,3250\left(\mathrm{NH}\right.$ and $\left.\mathrm{NH}_{2}\right)$, 3020 (CH aromatic), 2918, 2849 ( $\mathrm{CH}$ aliphatic), 1680 (CO), $1600(\mathrm{C}=\mathrm{N})$ and $1381 \mathrm{~cm}^{-1}$ (CS); ${ }^{1} \mathrm{H}$ NMR $\left(\mathrm{CDCl}_{3}\right): \delta 0.86\left(\mathrm{t}, 3 \mathrm{H}, \mathrm{CH}_{3}\right), 1.15-1.26(\mathrm{~m}$, $32 \mathrm{H}, \mathrm{CH}_{2}$ in alkyl chain), $2.09\left(\mathrm{t}, 2 \mathrm{H}, \mathrm{CH}_{2} \mathrm{NH}\right), 5.76$ (brs, $2 \mathrm{H}$, olefinic proton), 7.20-7.90 (m, 4H, ArH) and 8.41-9.34 (2 br.s, 4H, 2NH and $\mathrm{NH}_{2}$ ). Anal. Calcd for $\mathrm{C}_{30} \mathrm{H}_{47} \mathrm{~N}_{5} \mathrm{O}_{2} \mathrm{~S}$ (541.81): C, 66.51; $\mathrm{H}, 8.74 ; \mathrm{N}, 12.93$. Found C, 66.55; H, 8.79; N, 12.97.

\subsection{N-Octadecyl-3-(2-thioxo-2,3- dihydro[1,2,4]triazolo[1,5-c]quinazolin- 5-yl)acrylamide (11)}

Compound 11 was formed via dehydration of compound 10 by fusion in an oil bath at $120{ }^{\circ} \mathrm{C}$ for $2 \mathrm{hr}$. After cooling water was added and the solid obtained was filtered off and crystallized from xylene as brown needles, $75 \%$, mp $71-73^{\circ} \mathrm{C}$. IR: $v$ $3240(\mathrm{NH}), 3017$ (CH aromatic), 2919, $2850(\mathrm{CH}$ aliphatic), $1595(\mathrm{C}=\mathrm{N})$ and $1438 \mathrm{~cm}^{-1}(\mathrm{CS}) ;{ }^{1} \mathrm{H}$ NMR: $\left(\mathrm{CDCl}_{3}\right) \delta 0.96\left(\mathrm{t}, 3 \mathrm{H}, \mathrm{CH}_{3}\right), 1.29-1.33(\mathrm{~m}$, $32 \mathrm{H}, \mathrm{CH}_{2}$ in alkyl chain), 2.89 (t, $\left.2 \mathrm{H}, \mathrm{CH}_{2} \mathrm{NH}\right), 6.1$, 6.5 (2d, 2H,olefinic proton), 7.45-7.81 (m, $4 \mathrm{H}, \mathrm{ArH})$ and $8.2(\mathrm{~s}, 1 \mathrm{H}, \mathrm{NH})$; MS: $\mathrm{m} / \mathrm{z} 524$ (36.14) $\mathrm{M}^{+}+1$. Anal.Calcd for $\mathrm{C}_{30} \mathrm{H}_{45} \mathrm{~N}_{5} \mathrm{OS}$ (523.79): C,68.79; $\mathrm{H}, 8.66$; N,13.37.Found C,68.78; H,8.64; N,13.40.

\subsection{3-(3-Cyano-4-hydroxyquinolin-2-yl)- $\mathrm{N}$-octadecylacrylamide (12)}

Malononitrile (10 mmole) was added to $40 \mathrm{ml}$ of absolute ethanol containing (10 mmole). After a few minutes benzoxazinone 4 (10 mmole) was added. The reaction mixture was heated under reflux with stirring for 20. Most of the solvent was distilled off and the reaction solution was acidified with hydrochloric acid to give a crude product which was filtered off, washed several times with cold water, dried, and recrystallized from ethanol to yield 12 as brown needles, $70 \%$, mp 139-141 ${ }^{\circ} \mathrm{C}$. IR: v 3350 $(\mathrm{OH}), 3250(\mathrm{NH})$, 2919, 2850 (CH aliphatic), 1645 $(\mathrm{C}=\mathrm{N})$ and $2220 \mathrm{~cm}^{-1}(\mathrm{C} \equiv \mathrm{N}) .{ }^{1} \mathrm{H}$ NMR: $\left(\mathrm{CDCl}_{3}\right) \delta$ $0.94\left(\mathrm{t}, 3 \mathrm{H}, \mathrm{CH}_{3}\right), 1.29-1.30\left(\mathrm{~m}, 32 \mathrm{H}, \mathrm{CH}_{2}\right.$ in alkyl chain), 2.94 (t, $\left.2 \mathrm{H}, \mathrm{CH}_{2} \mathrm{NH}\right), 5.6,5.9$ (2d, $2 \mathrm{H}$, olefinic proton), 7.42-7.80 (m, $4 \mathrm{H}, \mathrm{ArH}), 8.9(\mathrm{~s}, 1 \mathrm{H}, \mathrm{NH})$ and 10.34 (s,1H, OH); MS: m/z 490 (25.22) $\mathrm{M}^{+}-1$. Anal. Calcd for $\mathrm{C}_{31} \mathrm{H}_{45} \mathrm{~N}_{3} \mathrm{O}_{2}$ (491.72): C,75.72; $\mathrm{H}, 9.22$; $\mathrm{N}, 8.55$.Found C,75.70; $\mathrm{H}, 9.22 ; \mathrm{N}, 8.52$.

\subsection{N-Octadecyl-3-(3-oxo-2-phenyl- 1-phenylcarbamoylimino-2,3-dihydro- 1H-4-oxa-2,9-diazaphenan-thren- 10-yl)acrylamide (13)}

A mixture of 12 (10 mmole) and phenyl isocyanate $(20 \mathrm{mmole})$ in $50 \mathrm{ml}$ of benzene was heated under reflux in the presence of catalytic amount of triethylamine for $12 \mathrm{~h}$. Removal of excess benzene afforded a crude solid after cooling. The crude solid was filtered off, dried and recrystallized 
from xylene to yield 13 as brown needles, $70 \%$, mp 139-141 ${ }^{\circ} \mathrm{C}$. IR: v $3220(\mathrm{NH}), 3017$ (CH aromatic), 2919, 2850 (CH aliphatic), 1667 (CO amide), 1704 (CO oxazinone) and $2220 \mathrm{~cm}^{-1}(\mathrm{C} \equiv \mathrm{N}) .{ }^{1} \mathrm{H}$ NMR: $\left(\mathrm{CDCl}_{3}\right) \delta 0.90\left(\mathrm{t}, 3 \mathrm{H}, \mathrm{CH}_{3}\right), 1.29-1.30\left(\mathrm{~m}, 32 \mathrm{H}, \mathrm{CH}_{2}\right.$ in alkyl chain), 2.90 (t, 2H, $\left.\underline{\mathrm{CH}}_{2} \mathrm{NH}\right), 6.5,6.8$ (2d, $2 \mathrm{H}$,olefinic proton), 5.79 (s, 2H, 2NH) and 7.42-7.80 (m, 14H, ArH). MS: m/z 729 (28.56) M $\mathrm{M}^{+}$. Anal.Calcd for $\mathrm{C}_{45} \mathrm{H}_{55} \mathrm{~N}_{5} \mathrm{O}_{4} \quad$ (729.97): $\mathrm{C}, 74.04 ; \mathrm{H}, 7.59$; N,9.59.Found C,74.09; H,7.62; N,9.59.

\subsection{3-Benzo[4,5]imidazo[1,2-c]quinazolin- 6-yl-N-octadecylacrylamide (14)}

Compound 4 was heated with ophenylenediamine above its melting point by fusion in an oil bath for $2 \mathrm{~h}$, then cooling water was added, the solid obtained was filtered off and crystallized from xylene to give 14 ; yield $76 \%$. mp $78{ }^{\circ} \mathrm{C}$. IR: $v$ $3280(\mathrm{NH}), 3010$ (CH aromatic), 2920-2850 (CH in alkyl chain), $1670(\mathrm{C}=\mathrm{O})$ and $1595 \mathrm{~cm}^{-1}(\mathrm{C}=\mathrm{N}) \cdot{ }^{1} \mathrm{H}$ NMR: $\left(\mathrm{CDCl}_{3}\right) \delta 0.90\left(\mathrm{t}, 3 \mathrm{H}, \mathrm{CH}_{3}\right), 1.29-1.30(\mathrm{~m}$, $32 \mathrm{H}, \mathrm{CH}_{2}$ in alkyl chain), $2.83\left(\mathrm{t}, 2 \mathrm{H}, \mathrm{CH}_{2} \mathrm{NH}\right), 5.7$, $5.9(2 \mathrm{~d}, 2 \mathrm{H}$,olefinic proton), $8.3(\mathrm{~s}, 1 \mathrm{H}, 1 \mathrm{NH})$ and 7.42-7.80 (m, 8H, ArH). MS: m/z 538 (32.13) $\mathrm{M}^{+}-2$. Anal.Calcd for $\mathrm{C}_{35} \mathrm{H}_{48} \mathrm{~N}_{4} \mathrm{O}$ (540.80): C,77.74; $\mathrm{H}, 8.95$; $\mathrm{N}, 10.36$. Found $\mathrm{C}, 77.76 ; \mathrm{H}, 8.94 ; \mathrm{N}, 10.36$.

\subsection{5. [2-(2-Octadecylcarbamoyl-vinyl)-4- oxo-4H-quinazolin-3-yl]acetic acid (15)}

A mixture of 4 (5 mmole) and glycine (5 mmole) was refluxed in ethanol $(30 \mathrm{ml})$ for $6 \mathrm{~h}$. The reaction mixture was concentrated and after cooling water was added and the solid obtained then filtered off and crystallized from ethanol to give 15 . Yield $73 \%$, mp $102{ }^{\circ} \mathrm{C}$. IR: v 3230 (NH), 3015 (CH aromatic), 2920-2850 (CH in alkyl chain), 1770 (C=O of acid), 1670 ( $\mathrm{C}=\mathrm{O}$ of amide) and $1595 \mathrm{~cm}^{-1}(\mathrm{C}=\mathrm{N}) .{ }^{1} \mathrm{H}$ NMR: $\left(\mathrm{CDCl}_{3}\right) \delta 0.86\left(\mathrm{t}, 3 \mathrm{H}, \mathrm{CH}_{3}\right), 1.23-1.30(\mathrm{~m}$, $32 \mathrm{H}, \mathrm{CH}_{2}$ in alkyl chain), $1.60\left(\mathrm{t}, 2 \mathrm{H}, \mathrm{CH}_{2} \mathrm{NH}\right), 3.55$ (s, $2 \mathrm{H}, \mathrm{CH}_{2} \mathrm{COOH}$ ), 5.5, 5.7 (2d, $2 \mathrm{H}$,olefinic proton), $8.0(\mathrm{~s}, 1 \mathrm{H}, 1 \mathrm{NH}), 7.25-7.90(\mathrm{~m}, 4 \mathrm{H}, \mathrm{ArH})$ and 9.98 (s, 1H, OH). Anal.Calcd for $\mathrm{C}_{31} \mathrm{H}_{47} \mathrm{~N}_{3} \mathrm{O}_{4}$ (525.74): C,70.82; H,9.01; N,7.99.Found C,70.80; H,9.00; $\mathrm{N}, 7.95$.

\subsection{6. $\mathrm{N}$-Octadecyl-3-(2-oxo-2,3-dihydro- 1H-3,4,9,10a-tetraazaphenanthren-10-yl)- acrylamide (16)}

A mixture of 15 (5 mmole) and hydrazine hydrate (5 mmole) was heated in boiling ethanol $(30 \mathrm{ml})$ under reflux for $6 \mathrm{~h}$. Then the mixture was poured into water. The precipitated solid was filtered off, dried and crystallized from ethanol to give 16. Yield $60 \%, \mathrm{mp} 65-67^{\circ} \mathrm{C}$. IR: v $3243(\mathrm{NH}), 3015(\mathrm{CH}$ aromatic), 2918, 2850 (CH aliphatic), 1685, 1660 two (CO) and $1609 \mathrm{~cm}^{-1}(\mathrm{C}=\mathrm{C})$; ms: $\mathrm{m} / \mathrm{z} 519$ (34.16) $\mathrm{M}^{+}$-2. Anal. Calcd for $\mathrm{C}_{31} \mathrm{H}_{47} \mathrm{~N}_{5} \mathrm{O}_{2}$ (521.75): C,71.36; $\mathrm{H}, 9.08$; N,13.42. Found C,71.35; $\mathrm{H}, 9.12 ; \mathrm{N}, 13.42$.

\subsection{Conversion of the prepared compounds $(4,16)$ to nonionic surfactants (17a-c -31a-c)}

They were prepared by the addition of $n$ moles of propylene oxide $(n=5,10,15)$ to one mol of suitable product using $\mathrm{KOH}$ as catalyst. A completed description of the procedure is given in (Morgos, et al., 1983). The amount of propylene oxide which was reacted and the average degree of propenoxylation were determined through the increment in mass of the reaction mixture (increase in weight of the mixture after the addition of propylene oxide is the average amount of propenoxylation) and also, by the ${ }^{1} \mathrm{H}$ NMR protons and these products were confirmed by spectroscopic methods. The addition of propylene oxide gave a mixture of propenoxylated products whose structures were confirmed by IR and ${ }^{1} \mathrm{H}$ NMR spectra. IR spectra showed two broad bands at 1100 and $950 \mathrm{~cm}^{-1}$ characteristic for $\nu \mathrm{C}-\mathrm{O}-\mathrm{C}$ ether linkage of polypropenoxy chain and ${ }^{1} \mathrm{H}$ NMR spectra showed the protons of propenoxy groups $\delta=3.2-3.7\left(\mathrm{~m},-\mathrm{CH}_{2} \mathrm{CH}\left(\mathrm{CH}_{3}\right)-\mathrm{O}\right)-$.

\subsection{Determination of the performance properties.}

Surface and interfacial tension were measured with a Du-Nouy tensiometer (Findly, 1963) (Kruss, Type 8451) using aqueous solution of surfactants $\left(0.1\right.$ wt \%) at room temperature $\left(25^{\circ} \mathrm{C}\right)$

Cloud point was determined by gradually heating a surfactant solution (1.0 wt \%) in a temperature controlled bath, and recording the temperature at which the clear, or nearly clear solutions become definitely turbid. The reproducibility of this temperature was checked by cooling the solutions until they become clear again (Wiel, et al., 1963).

Wetting time was determined by immersing a sample of cotton fabric in $1.0 \mathrm{wt} \%$ aqueous solution of surfactants (Draves, et al., 1931)

Foaming properties were measured according to (El-Sukkary, et al., 1987). In this procedure a 25 $\mathrm{ml}$ solution (1.0 wt \%) was shaken vigorously for 10 seconds in a $100 \mathrm{ml}$ graduated cylinder with a glass stopper at $25^{\circ} \mathrm{C}$. The solution was allowed to stand for 30 seconds, and then, the foam height was measured.

Emulsification stability was prepared from $10 \mathrm{ml}$ of a $20 \mathrm{mmol}$. aqueous solution of surfactant and 5 $\mathrm{ml}$ of toluene at $40^{\circ} \mathrm{C}$. Emulsion stability was determined as the time which took $9 \mathrm{ml}$ of the aqueous layer to separate from the emulsion counting from the cession of shaking (Takeshi, $\mathrm{H}$, 1970).

\subsection{Biodegradability}

Biodegradability was evaluated by surface tension measurements which were taken each day, on each sample during the degradation test. 
Biodegradation (Eter, E. T et al.,1974) percent (D) for each sample was calculated using the following equation : $\mathrm{D}=\left[\left(\gamma_{\mathrm{t}}-\gamma_{\mathrm{o}}\right) /\left(\gamma_{\mathrm{bt}}-\gamma_{\mathrm{o}}\right)\right] \times 100$, where $\gamma_{\mathrm{t}}=$ surface tension at time $t, \gamma_{0}=$ surface tension at zero time, $\gamma_{\mathrm{bt}}=$ surface tension of blank experiment at time $\mathrm{t}$ (without sample).

\subsection{Biological activity}

The antimicrobial activities of the synthesized surfactants were determined in vitro using the hole plate and filter paper disc method (Rosen, 1989). Compounds were dissolved in $10 \%$ acetone at different concentrations (125, 250, $500 \mu \mathrm{g} / \mathrm{ml})$. Agar plates were inoculated uniformly from fresh broth culture of Gram +ve, Gram -ve bacteria and fungi. The disks were incubated at $28^{\circ} \mathrm{C}$ for $24 \mathrm{~h}$, and the formed inhibition zones were measured in $\mathrm{mm}$.

\section{RESULTS AND DISCUSSION}

\subsection{Synthesis}

The nonionic surfactants produced in this work were prepared from hydrophobic substrate containing heterocyclic moiety. This substrate was prepared from 3-octadecyl-carbamoylacryloyl chloride (3) from 3octadecylcarbamoylacrylic acid (2) (which was prepared from octadecylamine (1) with maliec anhydride) followed by the reaction with thionyl chloride according to procedures described in (Eissa et al., 2006). Compound 3 was subjected to react with anthranilic acid in the presence of pyridine to produce $\mathrm{N}$-octadecyl-3-(4-oxo-4H-benzo[d][1,3]oxazin-2yl)acrylamide (4). (c.f. Scheme 1).

Reaction of 4 was used as target compound for the synthesis of different types of condensed and noncondensed heterocyclic compounds (c.f. Scheme 2).

Thus, when compound 4 was allowed to react with ammonium acetate by fusion it gave $N$ octadecyl-3-(4-oxo-3,4-dihydroquinazolin-2-yl)acrylamide (5). As described above quinazoline derivatives are of biological interest. Thus, the reaction of 4 with hydrazine hydrate afforded 3-(3amino-4-oxo-3,4-dihydroquinazolin-2-yl)- $N$ octadecyl-acrylamide (6) which cyclyzed to $\mathrm{N}$ octadecyl-3-(3-oxo-2,3-dihydro-1 H-1,4,9,10a-tetraa

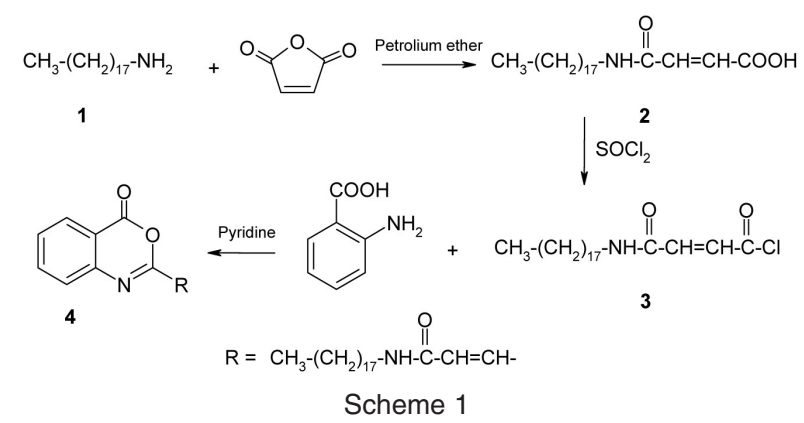

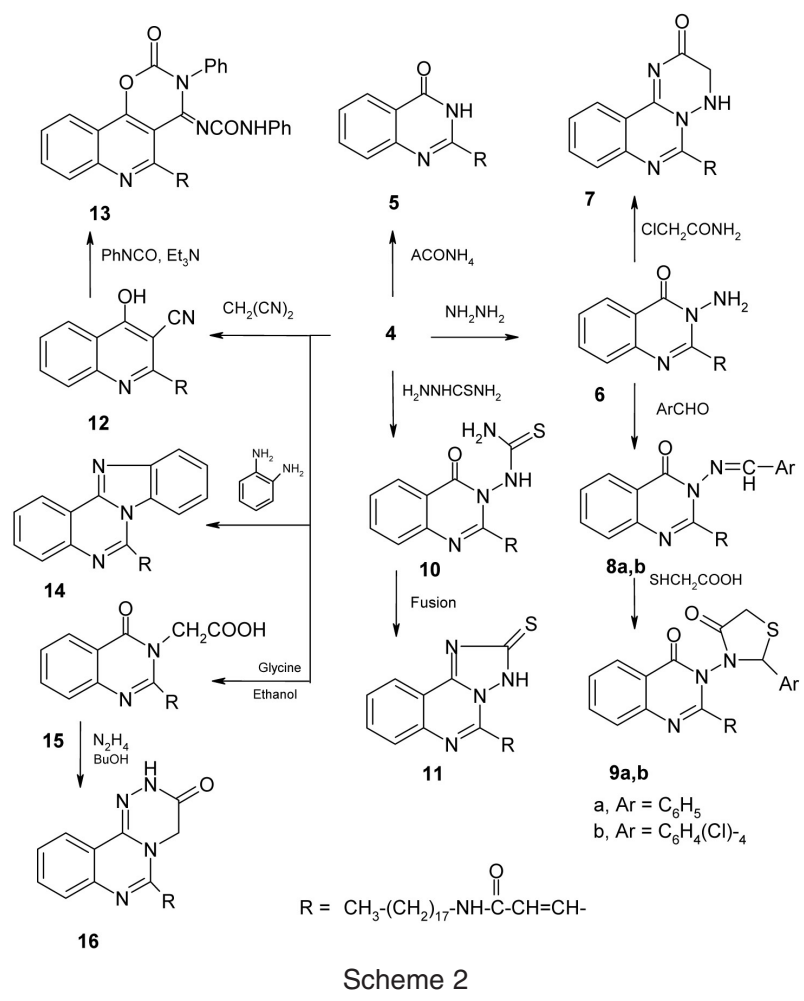

za-phenanthren-10-yl)acrylamide (7) by reaction with chloroacetamide in DMF.

On the other hand, compound 6 was treated with aldehydes (namely, benzaldehyde and/or pchlorobenzaldehyde) in ethanol to afford quinazolinone derivatives $(8 a, b)$ which converted to thiazolidine derivatives $(9 a, b)$ by reaction with thioglycollic acid in boiling butanol. Compound 4 was allowed to react with thiosemicarbazide and gave $\mathrm{N}$ octadecyl-3-(4-oxo-3-thioureido-3,4-dihydroquinazolin-2-yl)acrylamide (10) which when heated above its melting point and gave $\mathrm{N}$-octadecyl-3-(2thioxo-2,3-dihydro[1,2,4]triazolo[1,5-c]quinazolin-5yl)acrylamide (11).

Also, when malononitrile reacted with compound 4 it gave 3-(3-cyano-4-hydroxyquinolin-2-yl)- $N$ octadecylacrylamide (12) which cyclized to $\mathrm{N}$ heptadecyl-3-(3-oxo-2-phenyl-1-phenylcarbamoylimino-2,3-dihydro-1 H-4-oxa-2,9-diazaphenanthren10-yl)-acrylamide (13) by fusion with phenylisocyanate and triethyl amine.

In the last decade new communications have appeared describing the synthesis of pyrimidine derivatives which show important diverse biological activities (El-Sawy, et al., 1991). Herein, fusion of 4 with o-phenylenediamine above its melting point in an oil bath yielded a bridgehead nitrogen compound 14. Lastly, the reaction of 4 with glycine in butanol containing a few drops of water afforded [2-(2-octadecylcarbamoyl-vinyl)-4-oxo-4 Hquinazolin-3-yl]-acetic acid (15) which cyclized to $\mathrm{N}$ octadecyl-3-(2-oxo-2,3-dihydro-1H-3,4,9,10atetraaza-phenanthren-10-yl)acrylamide (16) via condens-ation with hydrazine hydrate in boiling butanol. 


\subsection{Conversion of the prepared compounds (4-16) to nonionic surfactants (17a-c-30a-c)}

Generally, for compounds acting as nonionic surface active agents two requirments are needed. The first one is that the hydrogen containing group present should be active enough to react with alkylene oxide and the second is that the molecular weight should be suitable to become an amphiphilic molecule with the suitable hydrophilic-lipophilic balance (Wasfy, et al., 1996). Reaction of all synthesized compounds (4-16) with different moles (n) of propylene oxide (where $n=5,10,15$ ) in the presence of $\mathrm{KOH}$ as catalyst gave the corresponding propenoxylated products (17a-c to $31 a-c)$, respectively. The reaction conditions are illustrated in Table 1. Scheme 3 shows the propenoxylation of compounds 5 and 6 as examples.

\subsubsection{Surface active properties}

The study of the surface active properties of the oxypropylated compounds has been done in an
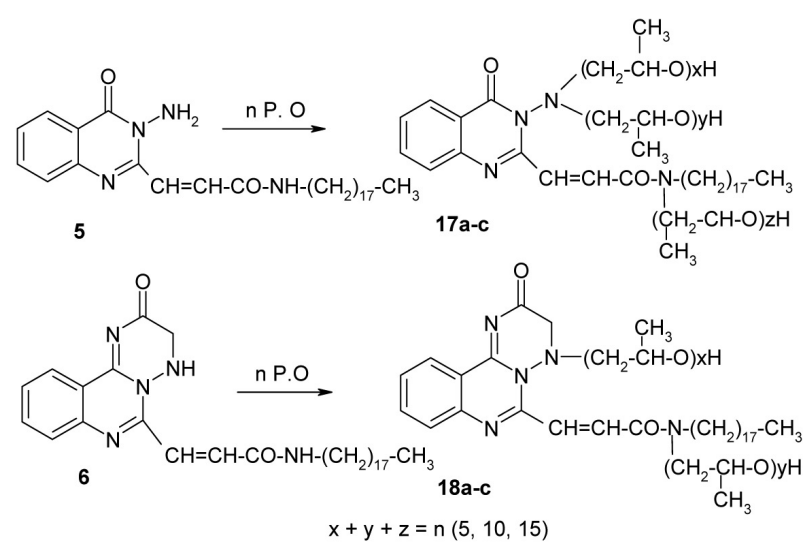

$$
\text { Scheme } 3
$$

Compounds 4-16 were propenoxylated at any active hydrogen $\left(\mathrm{OH}, \mathrm{NH}, \mathrm{SH}, \mathrm{NH}_{2}\right.$ and $\left.\mathrm{COOH}\right)$ to give products from $17 \mathrm{a}-\mathrm{c}$ to 31a-c, respectively. aqueous solution ( $1 \mathrm{wt} \%, \mathrm{pH}=7$ ) at $25^{\circ} \mathrm{C}$. The results are listed in Table 2.

\subsubsection{Surface and interfacial tension}

The surface and interfacial tension of the prepared compounds are shown in Table 2. It can be observed that the new nonionic surfactants have pronounced surface activity. In general, the surface and interfacial tensions increase with an increasing molecular weight of the hydrophilic moiety (Eissa et al., 2003). The data given in Table 2 shows that the values of surface and interfacial tension are increased with the increasing number of propylene oxide units added to the molecule.

\subsubsection{Cloud point}

A very important factor in making the most efficient use of nonionic surfactants in an aqueous system, at different temperatures, is a property known as cloud point. The data shows that the cloud points increased with an increasing number of propenoxy groups per hydrophobic molecule. The cloud points of the prepared surfactants were recorded in Table 2 and reflect the fact that it can be used over a wide range of temperatures.

\subsubsection{Wetting time}

All the prepared compounds showed a decrease in wetting time with an increase in the number of propylene oxide units in the molecule. The products are thus very effective as wetting agents and they can find a wide application in house hold detergents (Eissa, 1995).

\subsubsection{Foam power}

Foaming of the nonionic compounds was also studied. The foam height of the prepared surfactants

Table 1

Reaction conditions of propenoxylated compounds

\begin{tabular}{|c|c|c|c|c|c|}
\hline Compds & Catalyst, wt \% & Temperature ${ }^{\circ} \mathbf{C}$ & $\begin{array}{l}\text { Propoxylated } \\
\text { products }\end{array}$ & Yield \% & $\begin{array}{c}\text { Degree of } \\
\text { Propenoxylation } n^{*}\end{array}$ \\
\hline 4 & \multirow{15}{*}{$\mathrm{KOH}, 0.01$ wt \% } & \multirow{15}{*}{$120-125$} & $17 a-c$ & $60-55$ & \multirow{15}{*}{5,10 and 15} \\
\hline 5 & & & $18 a-c$ & $60-65$ & \\
\hline 6 & & & $19 a-c$ & $71-67$ & \\
\hline 7 & & & $20 a-c$ & $82-78$ & \\
\hline $8 a$ & & & $21 a-c$ & $72-66$ & \\
\hline $8 b$ & & & $22 a-c$ & $80-75$ & \\
\hline $9 a$ & & & $23 a-c$ & $60-58$ & \\
\hline $9 b$ & & & $24 a-c$ & $72-66$ & \\
\hline 10 & & & $25 a-c$ & $72-66$ & \\
\hline 11 & & & $26 a-c$ & $70-66$ & \\
\hline 12 & & & $27 a-c$ & $63-59$ & \\
\hline 13 & & & $28 a-c$ & $80-75$ & \\
\hline 14 & & & $29 a-c$ & $66-68$ & \\
\hline 15 & & & $30 a-c$ & $78-80$ & \\
\hline 16 & & & $31 a-c$ & $65-67$ & \\
\hline
\end{tabular}

$n^{*}$ Degree of propenoxylation was calculated by weight 
Table 2

Surface properties of nonionic compounds.

\begin{tabular}{|c|c|c|c|c|c|c|c|}
\hline Compd. & $\mathrm{n}^{\mathrm{b}}$ & $\begin{array}{c}\text { Surface } \\
\text { Tension } \\
\text { (dyne/cm) } \\
0.1 \mathrm{~m} / \mathrm{l}\end{array}$ & $\begin{array}{c}\text { Interfacial } \\
\text { tension } \\
\text { (dyne/cm) } \\
0.1 \mathrm{~m} / \mathrm{l}\end{array}$ & $\begin{array}{l}\text { Cloud } \\
\text { Point } \\
{ }^{\circ} \mathrm{C}\end{array}$ & $\begin{array}{l}\text { Wetting } \\
\text { time } \\
\text { (sec.) }\end{array}$ & $\begin{array}{c}\text { Emulsion } \\
\text { stability } \\
\text { (min.) }\end{array}$ & $\begin{array}{c}\text { Foam } \\
\text { height } \\
(\mathrm{mm})\end{array}$ \\
\hline $17 a$ & 5 & 33 & 8.0 & 54 & 45 & 120 & 104 \\
\hline $17 \mathrm{~b}$ & 10 & 36 & 9.5 & 66 & 37 & 92 & 134 \\
\hline $17 c$ & 15 & 40 & 10.5 & 75 & 25 & 80 & 151 \\
\hline $18 a$ & 5 & 31 & 10.0 & 67 & 45 & 71 & 95 \\
\hline $18 b$ & 10 & 35 & 13.0 & 67 & 26 & 67 & 120 \\
\hline $18 c$ & 15 & 41 & 16.0 & 91 & 17 & 63 & 140 \\
\hline $19 a$ & 5 & 32 & 10.0 & 69 & 49 & 125 & 78 \\
\hline $19 b$ & 10 & 36 & 11.0 & 81 & 33 & 96 & 124 \\
\hline $19 c$ & 15 & 40 & 12.5 & 90 & 25 & 76 & 142 \\
\hline $20 a$ & 5 & 30 & 7.5 & 77 & 43 & 70 & 105 \\
\hline $20 \mathrm{~b}$ & 10 & 34 & 9.0 & 90 & 31 & 72 & 130 \\
\hline $20 c$ & 15 & 37 & 10.5 & 99 & 20 & 63 & 160 \\
\hline $21 a$ & 5 & 32 & 9.0 & 73 & 53 & 120 & 90 \\
\hline $21 b$ & 10 & 37 & 11.5 & 92 & 37 & 95 & 100 \\
\hline $21 c$ & 15 & 43 & 14.0 & 99 & 26 & 89 & 120 \\
\hline $22 a$ & 5 & 33 & 8.0 & 70 & 51 & 112 & 97 \\
\hline $22 b$ & 10 & 38 & 9.0 & 87 & 35 & 82 & 128 \\
\hline $22 c$ & 15 & 44 & 11.5 & 98 & 26 & 73 & 148 \\
\hline $23 a$ & 5 & 37 & 8.0 & 63 & 44 & 96 & 115 \\
\hline $23 b$ & 10 & 34 & 10.0 & 75 & 33 & 88 & 135 \\
\hline $23 c$ & 15 & 32 & 11.5 & 96 & 25 & 78 & 155 \\
\hline $24 a$ & 5 & 30 & 7.5 & 77 & 43 & 70 & 105 \\
\hline $24 b$ & 10 & 34 & 9.0 & 90 & 31 & 72 & 130 \\
\hline $24 c$ & 15 & 37 & 10.5 & 99 & 20 & 63 & 160 \\
\hline $25 a$ & 5 & 33 & 10.5 & 67 & 49 & 106 & 89 \\
\hline $25 b$ & 10 & 37 & 12.0 & 83 & 33 & 96 & 110 \\
\hline $25 c$ & 15 & 39 & 13.5 & 94 & 25 & 75 & 130 \\
\hline $26 a$ & 5 & 35 & 9.0 & 59 & 42 & 95 & 120 \\
\hline $26 b$ & 10 & 38 & 10.5 & 77 & 35 & 85 & 130 \\
\hline $26 c$ & 15 & 40 & 12.0 & 89 & 27 & 70 & 155 \\
\hline $27 a$ & 5 & 35 & 8.5 & 64 & 47 & 90 & 90 \\
\hline $27 b$ & 10 & 38 & 10.5 & 82 & 36 & 79 & 110 \\
\hline $27 c$ & 15 & 41 & 13.0 & 93 & 25 & 64 & 140 \\
\hline $28 a$ & 5 & 31 & 7.5 & 76 & 42 & 94 & 118 \\
\hline $28 b$ & 10 & 35 & 9.5 & 86 & 30 & 86 & 138 \\
\hline $28 c$ & 15 & 39 & 10.0 & 97 & 22 & 76 & 158 \\
\hline $29 a$ & 5 & 31 & 8.5 & 73 & 39 & 110 & 95 \\
\hline $29 b$ & 10 & 36 & 10.5 & 85 & 31 & 98 & 120 \\
\hline $29 c$ & 15 & 39 & 11.5 & 93 & 23 & 80 & 150 \\
\hline $30 a$ & 5 & 32 & 8.5 & 70 & 43 & 130 & 112 \\
\hline $30 \mathrm{~b}$ & 10 & 34 & 9.5 & 83 & 31 & 98 & 135 \\
\hline $30 c$ & 15 & 36 & 10.5 & 91 & 20 & 77 & 213 \\
\hline $31 a$ & 5 & 33 & 10.5 & 67 & 49 & 106 & 89 \\
\hline $31 b$ & 10 & 38 & 10.5 & 77 & 35 & 85 & 130 \\
\hline $31 c$ & 15 & 41 & 13.0 & 93 & 25 & 64 & 140 \\
\hline
\end{tabular}

a) Error was: surface and interfacial tensions $= \pm 0.1 \mathrm{dynes} / \mathrm{cm}$; cloud point $= \pm 1^{\circ} \mathrm{C}$; foam height $= \pm 2 \mathrm{~mm}$; wetting time $= \pm 1 \mathrm{sec}$; emulsion $= \pm 1 \mathrm{~min}$ b) $\mathrm{n}$ in the number of propylene oxide added to the chosen compound 
Table 3

Biodegradability of the prepared surfactants

\begin{tabular}{|c|c|c|c|c|c|c|c|c|}
\hline Compds. & $\mathrm{n}^{\mathrm{a}}$ & $1^{\text {st }}$ day & $2^{\text {nd }}$ day & $3^{\text {rd }}$ day & $4^{\text {th }}$ day & $5^{\text {th }}$ day & $6^{\text {th }}$ day & $7^{\text {th }}$ day \\
\hline $17 a$ & 5 & 51 & 68 & 79 & 84 & 96 & - & - \\
\hline $17 \mathrm{~b}$ & 10 & 48 & 65 & 74 & 80 & 90 & - & - \\
\hline $17 c$ & 15 & 45 & 61 & 72 & 79 & 85 & 93 & - \\
\hline $18 a$ & 5 & 48 & 60 & 68 & 78 & 89 & - & - \\
\hline $18 b$ & 10 & 45 & 56 & 66 & 73 & 76 & 98 & - \\
\hline $18 \mathrm{c}$ & 15 & 41 & 51 & 64 & 70 & 73 & 80 & - \\
\hline $19 a$ & 5 & 49 & 62 & 70 & 79 & 86 & 92 & - \\
\hline $19 b$ & 10 & 46 & 56 & 69 & 74 & 83 & 88 & - \\
\hline $19 c$ & 15 & 40 & 51 & 67 & 70 & 79 & 83 & - \\
\hline $20 a$ & 5 & 53 & 65 & 71 & 81 & 93 & - & - \\
\hline $20 b$ & 10 & 48 & 59 & 69 & 77 & 80 & 91 & - \\
\hline $20 c$ & 15 & 45 & 57 & 67 & 74 & 78 & 88 & - \\
\hline $21 a$ & 5 & 55 & 55 & 62 & 79 & 87 & 90 & - \\
\hline $21 b$ & 10 & 49 & 51 & 59 & 67 & 78 & 88 & - \\
\hline $21 c$ & 15 & 47 & 48 & 57 & 63 & 72 & 85 & - \\
\hline $22 a$ & 5 & 53 & 58 & 66 & 80 & 82 & 93 & - \\
\hline $22 b$ & 10 & 50 & 56 & 63 & 71 & 79 & 96 & - \\
\hline $22 c$ & 15 & 49 & 54 & 59 & 68 & 95 & - & - \\
\hline $23 a$ & 5 & 57 & 62 & 71 & 79 & 85 & 93 & - \\
\hline $23 b$ & 10 & 55 & 57 & 69 & 73 & 83 & 90 & - \\
\hline $23 c$ & 15 & 52 & 52 & 68 & 71 & 79 & 87 & - \\
\hline $24 a$ & 5 & 48 & 60 & 68 & 78 & 89 & - & - \\
\hline $24 b$ & 10 & 45 & 56 & 66 & 73 & 76 & 98 & - \\
\hline $24 c$ & 15 & 41 & 51 & 64 & 70 & 73 & 80 & - \\
\hline $25 a$ & 5 & 49 & 66 & 79 & 89 & 96 & - & - \\
\hline $25 b$ & 10 & 48 & 63 & 73 & 86 & 95 & - & - \\
\hline $25 c$ & 15 & 43 & 59 & 71 & 79 & 88 & 96 & - \\
\hline $26 a$ & 5 & 50 & 62 & 68 & 79 & 92 & - & - \\
\hline $26 b$ & 10 & 47 & 55 & 63 & 72 & 80 & 93 & - \\
\hline $26 c$ & 15 & 43 & 49 & 45 & 65 & 77 & 91 & - \\
\hline $27 a$ & 5 & 54 & 54 & 60 & 77 & 80 & 93 & - \\
\hline $27 b$ & 10 & 48 & 52 & 57 & 65 & 76 & 90 & - \\
\hline $27 c$ & 15 & 45 & 49 & 54 & 61 & 73 & 86 & - \\
\hline $28 a$ & 5 & 55 & 63 & 73 & 78 & 85 & 95 & - \\
\hline $28 b$ & 10 & 52 & 59 & 70 & 75 & 85 & 92 & - \\
\hline $28 c$ & 15 & 49 & 54 & 69 & 73 & 81 & 91 & - \\
\hline $29 a$ & 5 & 54 & 63 & 73 & 84 & 95 & - & - \\
\hline $29 b$ & 10 & 48 & 55 & 67 & 79 & 92 & - & - \\
\hline $29 c$ & 15 & 45 & 50 & 61 & 72 & 84 & 93 & - \\
\hline $30 a$ & 5 & 55 & 67 & 75 & 85 & 95 & - & - \\
\hline $30 b$ & 10 & 52 & 59 & 71 & 82 & 92 & - & - \\
\hline $30 c$ & 15 & 50 & 56 & 61 & 75 & 88 & 93 & - \\
\hline $31 a$ & 5 & 49 & 66 & 79 & 89 & 96 & - & - \\
\hline $31 b$ & 10 & 47 & 55 & 63 & 72 & 80 & 93 & - \\
\hline $31 c$ & 15 & 45 & 49 & 54 & 61 & 73 & 86 & - \\
\hline
\end{tabular}

a) $n$ is the number of moles of propylene oxide added to the chosen compound Error of calculations was: Biodegradation rate $= \pm 0.5 \%$ 
Table 4

Response of various microorganisms to nonionic compounds in vitro

\begin{tabular}{|c|c|c|c|c|c|c|c|c|}
\hline \multirow{2}{*}{ Compd } & \multicolumn{2}{|c|}{ Bacillus cereus } & \multicolumn{2}{|c|}{ Escherichia coli } & \multicolumn{2}{|c|}{ Aspergillus niger } & \multicolumn{2}{|c|}{ Pencicillium notatum } \\
\hline & $\mathbf{A}$ & MIC ( $\mu \mathrm{g} / \mathrm{ml})$ & A & MIC ( $\mu \mathrm{g} / \mathrm{ml})$ & A & MIC $(\mu \mathrm{g} / \mathrm{ml})$ & $\mathbf{A}$ & MIC $(\mu \mathrm{g} / \mathrm{ml})$ \\
\hline $17 a$ & + & 250 & - & - & + & 250 & ++ & 125 \\
\hline $17 b$ & + & 125 & + & 250 & ++ & 125 & + & 250 \\
\hline $17 \mathrm{c}$ & ++ & 250 & ++ & 250 & ++ & 250 & ++ & 125 \\
\hline $18 a$ & + & 125 & ++ & 250 & + & 125 & ++ & 125 \\
\hline $18 b$ & + & 125 & + & 250 & ++ & 250 & + & 250 \\
\hline $18 c$ & ++ & 250 & - & 125 & ++ & 125 & ++ & 250 \\
\hline $19 a$ & - & 125 & + & 250 & + & 250 & + & 250 \\
\hline $19 b$ & ++ & 250 & - & 125 & + & 125 & ++ & 250 \\
\hline $19 c$ & + & 250 & + & 250 & + & 125 & + & 125 \\
\hline $20 a$ & - & 125 & - & 125 & + & 250 & - & 125 \\
\hline $20 b$ & ++ & 250 & - & 125 & ++ & 125 & + & 125 \\
\hline $20 c$ & + & 125 & ++ & 250 & +++ & 125 & ++ & 125 \\
\hline $21 a$ & + & 250 & - & 125 & + & 250 & - & 125 \\
\hline $21 b$ & + & 125 & + & 250 & ++ & 125 & + & 250 \\
\hline $21 c$ & ++ & 250 & - & 125 & + & 125 & + & 125 \\
\hline $22 a$ & + & 125 & ++ & 250 & + & 125 & ++ & 125 \\
\hline $22 b$ & + & 125 & + & 250 & ++ & 250 & + & 250 \\
\hline $22 c$ & ++ & 250 & - & 125 & ++ & 125 & ++ & 250 \\
\hline $23 a$ & + & 250 & + & 250 & - & 125 & + & 125 \\
\hline $23 b$ & - & 125 & - & 125 & + & 250 & - & 125 \\
\hline $23 c$ & ++ & 250 & - & 125 & + & 125 & + & 125 \\
\hline $24 a$ & + & 125 & ++ & 250 & + & 125 & ++ & 125 \\
\hline $24 b$ & + & 250 & - & 125 & ++ & 250 & - & 125 \\
\hline $24 c$ & + & 125 & + & 250 & ++ & 125 & + & 250 \\
\hline $25 a$ & + & 250 & - & 125 & + & 125 & + & 125 \\
\hline $25 b$ & + & 125 & ++ & 250 & ++ & 125 & ++ & 125 \\
\hline $25 c$ & - & 125 & + & 250 & ++ & 250 & + & 250 \\
\hline $26 a$ & ++ & 250 & - & 125 & + & 125 & ++ & 250 \\
\hline $26 \mathrm{~b}$ & + & 250 & + & 250 & - & 125 & + & 125 \\
\hline $26 c$ & + & 125 & - & 125 & + & 250 & + & 125 \\
\hline $27 a$ & + & 125 & + & 250 & + & 250 & + & 250 \\
\hline $27 b$ & ++ & 250 & + & 125 & + & 125 & ++ & 250 \\
\hline $27 c$ & + & 250 & + & 250 & - & 125 & + & 125 \\
\hline $28 a$ & + & 125 & + & 125 & + & 250 & - & 125 \\
\hline $28 b$ & ++ & 250 & + & 125 & + & 125 & + & 125 \\
\hline $28 c$ & + & 125 & ++ & 250 & +++ & 125 & ++ & 125 \\
\hline $29 a$ & ++ & 250 & + & 125 & + & 250 & - & 125 \\
\hline $29 b$ & + & 125 & + & 250 & ++ & 125 & + & 250 \\
\hline $29 c$ & + & 250 & ++ & 125 & + & 125 & + & 125 \\
\hline $30 a$ & + & 125 & ++ & 250 & ++ & 125 & ++ & 125 \\
\hline $30 \mathrm{~b}$ & ++ & 250 & + & 125 & ++ & 125 & ++ & 250 \\
\hline $30 c$ & + & 250 & + & 250 & ++ & 125 & + & 125 \\
\hline $31 a$ & + & 250 & - & 125 & + & 125 & + & 125 \\
\hline $31 b$ & + & 250 & + & 250 & - & 125 & + & 125 \\
\hline $31 c$ & + & 250 & + & 250 & - & 125 & + & 125 \\
\hline
\end{tabular}

A; Antimicrobial activity of tested compounds; the width of the zone of inhibition indicates the potency of antimicrobial activity, (-) no antimicrobial activity, $(+)$ weak activity with diameter equal to $(0.5-0.7 \mathrm{~cm}),(++)$ moderate activity with the diameter zone equal to $(1.0-1.2 \mathrm{~cm}),(+++)$ marked activity with the diameter zone equal to $(1.6-1.8 \mathrm{~cm})$. MIC; Minimum inhibition concentration in $\mu \mathrm{g} / \mathrm{ml}$. 
increases with an increase in the propylene oxide units per molecule of surfactant. The low foaming power could have an application in dyeing auxiliary industry (Somaya, et al., 1998).

\subsubsection{Emulsion stability}

Studies are still being carried out on the utilization of surfactants in emulsions formulation which are of immense importance for technological development. It was proved that the prepared surfactants exhibit good emulsifying properties. Emulsion stability increases with a decrease in the number of propylene oxide units. The results recorded that all synthesized nonionic compounds exhibit good emulsification time and these results might lead to the application of the surfactants of choice in the formulation of pesticides and cosmetics .

\subsubsection{Biodegradability}

The trend of degradation in river die-away tests was followed by the surface tension measurements. The results are given in Table 3 . The rate of degradation of these compounds depended on the size of the molecule; a bulky molecule diffuses difficulty through the cell membrane, and its degradation is more difficult. This means that molecules with a low proportion of propylene oxide are more degradable than those containing a higher proportion.

\subsubsection{Biological activity}

As show in Table 4 most of the synthesized surfactants have remarkable antimicrobial activity towards the selected bacteria and fungi. The presence of heterocyclic moiety in the prepared nonionic surfactant molecule revealed an increase in the biological activity. It is therefore clear that these surfactants were effective and inhibited the growth of all tested microorganisms.

\section{CONCLUSION}

It can be concluded that all the prepared nonionic surfactants which containing heterocyclic moieties have a double functions as antimicrobial and surface active agents with good emulsifying and wetting properties. They can have applications in the non edible media such as insecticides, pesticides, drugs, cosmetics and house hold detergents.

\section{AKNOWLDGMENTS}

Origin of cultures: Botany Department, Faculty of Science, Benha University, Egypt.

\section{BIBLOGRAPHY}

Amin MS, Eissa AM. F, Shaaban AF, El-Sawy AA and ElSayed R. 1998. Utilization of 2-(2-carboxyethyl)$4(3 H)$-quinazolinethione in the synthesis of condensed and noncondensed heterocycles. Indian. J. Heterocycl. Chem. 7, 289.

Amin MS, Eissa AMF, Shaaban AF, El-Sawy AA and ElSayed R. 2003. New heterocycles having double characters as antimicrobial and surface active agents. Part 2: Anionic compounds from fatty acid isothiocyanate. Chemistry: An Indian Journal 51, 155.

Amin MS, Eissa AMF, Shaaban AF, El-Sawy AA and ElSayed R. 2004. New heterocycles having a double characters;as antimicrobial and surface active agents.Part 1: Nonionic compounds from fatty acid isothiocyanate. Grasas y Aceites 55, 370-377.

Amin MS, Eissa AMF, Shaaban AF, El-Sawy AA and ElSayed R. 2004. New heterocycles having double characters as antimicrobial and surface active agents.Part 3: Nonionic compounds from fatty acid hydrazide. Olaj, Szappan, Kozmetika 53, 124.

Draves CZ and Clarkso R. 1931. J. Am. Dye Stuff Reporter 20, 201.

Eissa AMF and El-Sayed R. 2006. Synthesis and Evaluation of Condensed and Noncondensed Heterocyclic Compounds of Industrial Application. J. Heterocyclic. Chemistry 43, 1.

Eissa AF. 2006. Grasas y Aceites 57, 319-327.

El-Sawy AA, Essawy SA, El-Sukkary MM and Eissa AMF. 1991. Surfactants from 2-hydroxy fatty acids: II. Esters from 2-hydroxy fatty acids and hydroxy alkane sulphonate. J. Serb. Chem. Soc. 56, 145-149.

Eissa AMF, Ahmed MHM. 2003. Nonionic surface active agents containing heterocyclic moieties. J. Olaj, Szappan, Kozmetika 52, 11-17.

Eissa AMF. 1995. Amphoteric surface active agents. Grasas y Aceites 46, 240-244.

El-Sukkary MA, El-Sawy AA. and El-Dib F. 1987. Synthetic detergents from crude rice bran oil. Hungarian Journal of Industrial Chemistry 15, 317322.

Eter ET, Richard RE and Darid A. 1974. Biodegradable surfactants derived from corn starch. J. Am. Oil Chem. Soc. 51, 486-491.

Findly A. 1963. Practical physical chemistry. $6^{\text {th }}$ Ed. Longmans, London.1040.

Lagerman R, Clancy S, Tanner D, Johnston N, Callian B and Friedli F. 1994. J. Am. Oil Chem. Soc. 71, 97-100

Morgos J, Sallay P, Farkas L and Rus Znar I. 1983. J. Am. Oil Chem. Soc. 60, 11.

Pegiadou S. Perez L and Infante MR. 2001. J. Surfactants and Detergents 3, 517-525.

Pegiadou K, Papazoglou V and Kehayoglou A. 2000. J. Surfactants and Detergents 3, 73-76.

Rosen MJ. 1989. $2^{\text {th }}$ Ed., John Wiley \& Sons, New York. 286.

Sallary P, Bekassy S, Ahmed MH, Farkas I and Rusznak I. 1997. Tetrahedron Letters 38, 661-664.

Somaya AR, Eissa AMF, Nadia A and Ahmad MN. 1998. Synthesis and characterization of some peptides having surface activity using polyethylene glycol. J. Pharm. Sci. 7, 27.

Takeshi H. 1970. Studies of ester containing surfactant: Preparation and properties of sodium sulphalkanoates. Bull. Chem. Soc. 43, 2236.

Wasfy AAF, Yassin FA and Eissa AMF. 1995. Synthesis and reactions of (2-methylquinazol-4-oxy) acetic acid hydrazide. Indian. J. Chem. 34B, 537. 
Wasfy AAF, Amin MS and Eissa AMF. 1996. Synthesis and reactions of 6(4)-(p.benzylphenyl)-4(6) phenylpyrimidine 2(1H) thione. Heterocyclic Communications. 2,4, 375381.

Wiel JK, Smith FD, Stirton AJ and Bistine RG. 1963. Long chain alkanesulphonates and 1-hydroxy-2alkanesulphonates: Structure and property relations. J. Am. Oil. Chem. Soc. 40, 538.
Yassin FA, Eissa AMF and Wasfy AAF. 1994. Synthesis and reactions of 3-amino-2-methyl-4-(3H)-quinazolinone derivatives. Indian. J. Chem. 33B, 1195.

Recibido: $11 / 6 / 07$ Aceptado: 19/7/07 